\title{
Digital Learning in Russian Higher Education: What Are Lecturers Attitude and Fears Toward Online Courses Adoption?
}

\author{
Svetlana V. Lobova \\ Altai State University \\ Elena V. Ponkina \\ Altai State University
}

Online courses changed the landscape of higher education in the World, but their acceptance by lecturers in Russian universities is incomplete. The study aims to reveal a general attitude of online courses among lecturers in Russian universities; to quantify factors that motivate lecturers to create and modify online courses; to identify lecturers' fears regarding their employment status due to the widespread adoption of online courses into the practice of higher education. The quantitative study is based on the results of a lecturers' survey, which was conducted in 2020 in Russian universities. We filled 134 questionnaires using the Google form. The result contributes to (i) a scientific discussion about the role, meaning, and effects of online courses inclusion into educational programs (in the context of factors and motives for creating and addressing them by the lecturers), and it enriched the scope of scientific literature, dedicated to e-learning in higher education, and (ii) empirical results confirmed that acceptance of online courses in the systems of higher vocational education is viewed through the prism of employment threats.

Keywords: digital education, e-learning, online courses, higher education, lecturers, attitude, employment threats, OER Adoption Pyramid, Russia

\section{INTRODUCTION}

Digitalization and large-scale implementation of e-learning are the main trends in the development of leading Russian universities. The most common form of e-learning in universities is online courses, one of the types of open educational resources (OERs). It is believed that the popularity of so-called Massive Open Online Courses (MOOCs) began in 2012, which in this context became known as the year of MOOCs (Pappano, 2012).

Since then, researchers and practitioners have discussed the feasibility and effectiveness of online courses usage in higher education publications and have presented arguments for and against them. Elearning advocates prove that online courses (i) make high-quality education more accessible (Friedman, 2013; Literat, 2015), (ii) reduce students' expenses for higher education, while the released resources can be used to meet other needs (Ikahihifo et al., 2017), (iii) optimize the economy of educational organizations (Online Learning..., 2015), (iv) help promote universities' brands (Roshchina et al., 2018), (v) expand the horizons of cooperation between colleagues (Chae \& Jenkins, 2015), (vi) improve teaching skills and technologies (Rolfe, 2017; Chekhonina \& Kuznetsova, 2019), including by critically 
understanding their own teaching practices (Weller at al., 2015) and improving access to educational materials (Hennessy at al., 2015), and (vii) help overcome the "curse of the province" by providing regional universities with access to the best information resources.

Opponents and critics of distance education point out that online courses are tools for saving on academic hours and full-time faculty (Tulchinskii, 2017), including artfully disguised advertising materials of authors, universities, and platform providers, have commercial goals (Daniel, 2012) and can serve for profit by premier universities (Marshall, 2014). Their implementation is associated with a weak motivation of students to study independently, and the lack of readiness of universities to organizational changes, in particular, to change the composition of employees in favor of creating a staff of tutors, assessors, and technical specialists who accompany the learning process are an undeveloped economic basis for the interaction between selling and purchasing universities (Tretyakov \& Larionova, 2016), and their pedagogical qualities and pedagogical value are questionable (Zakharova \& Tanasenko, 2019). We believe these conclusions are more suitable for MOOCs than for Mass Closed Online Courses (MCOCs). Proponents of online education define MCOCs as university online courses (Online Learning..., 2015).

The purposes of this study were $(i)$ to reveal the general attitude of lecturers toward online courses introduction in Russian universities; (ii) to quantify factors that motivate lecturers to create and modify online courses; (iii) to identify lecturers' fears regarding their employment status due to the widespread adoption of online courses into the practice of higher education. We believe the results of empirical research presented in the public domain do not adequately disclose these issues, the relevance of which, in our opinion, is not in doubt.

The paper structure is as follows: firstly, we considered the theoretical framework and reviewed the alternative quantitative studies on the adoption of online courses in Russian universities; secondly, we described stages of sociological survey design and data collection via an electronic questionnaire as well as descriptive statistics of the entire sample; thirdly, we reported results of quantification of the general attitude of lecturers to online courses, to quantify fears of lecturers due to online courses introduction in higher education, we employed logit regression model; finally, we discussed results and its contribution to ongoing discussions and generated ideas on the attitude to online courses from the faculty.

\section{THEORETICAL FRAMEWORK}

The inclusion of online courses in the educational process, as a necessary element, transforms learning technologies and changes the content of faculty' activities, and imposes new requirements on them. Russian researchers noted the transformation of faculty' competencies and changes in their positioning and content of work.

Mozhaeva (2019) summarized the requirements for mandatory and optional competencies of faculty involved in implementing online courses. These include (a) the readiness and ability to integrate online courses into the curriculum of disciplines and individual educational trajectories of students, (b) applying reliable and objective criteria and methods for evaluating the effectiveness of online learning, (c) manage learning by making maximum use of the information and educational environment of your organization and the online platform, (d) provide practical advice when organizing and supporting project activities of students in the virtual space, (e) the ability to motivate students to study in online courses, and (f) the ability to identify internal problems in the online course (organizational, technical, methodological, substantive).

Kuznetsov (2019) articulates that a modern lecturer must simultaneously combine three different types of competencies: he must be a specialist in the subject area (and preferably with practical experience), he must be a lecturer who owns modern educational technologies, and he must have the necessary digital competencies (i.e., must be an advanced user of the modern information systems). We should note that the process of teaching through online platforms requires several specific skills, such as the ability to "hold yourself in front of the camera," which is different from the ability to give a 
lecture to a familiar audience. Tulchinskii (2017) holds a similar position to Kuznetsov. He points out that working online faculty is not so much a source of knowledge, but rather navigators who offer the optimal trajectory for this course to get acquainted with databases, develop practical tasks, cases for discussion, and, of course, test students. If a faculty or educational program manager wants to use some online courses, they have to take these courses themselves to understand their capabilities. These circumstances may be factors of acceptance or rejection by faculty and their formed adoption to online learning.

South African researchers Cox and Trotter (2017), studying the lecturers' adoption of OER, developed the OER Adoption Pyramid, which is based on the idea of the Maslow's hierarchy of needs. We have interpreted the Cox \& Trotter's pyramid in relation to our research (Figure 1).

\section{AUTHORS' INTERPRETATION COX \& TROTTER'S OER ADOPTION PYRAMID}

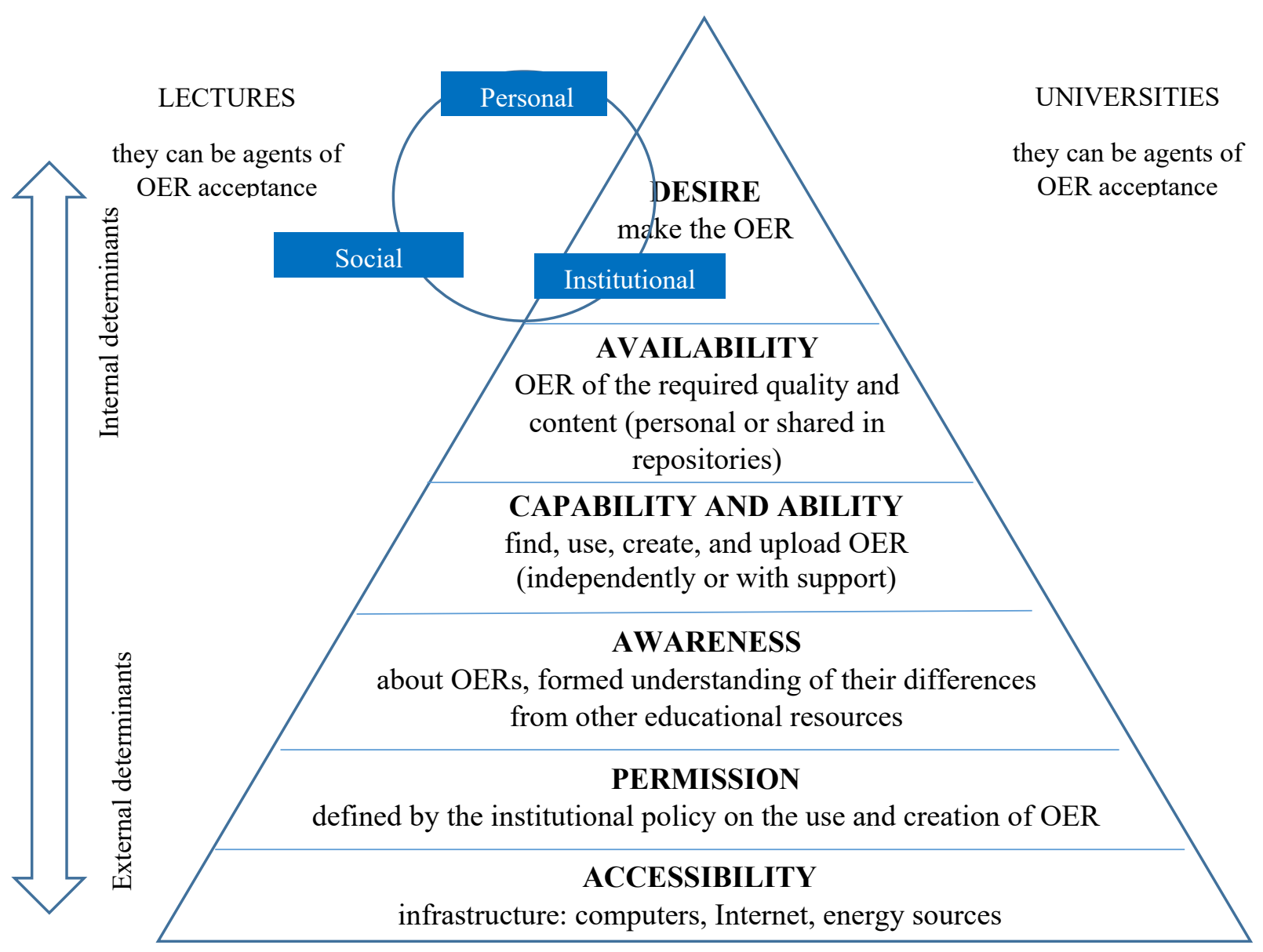

Cox \& Trotter, 2017

The lecturers' OER adoption is regulated by six types of factors determined by the level of influence and control over them on the part of the lecturers: at the bottom of the pyramid are factors determined from outside, and at the top - factors formed by the ability and desire to implement OER in their activities (Cox \& Trotter, 2017). At the top of the pyramid, the faculty's willingness to accept, apply, and create OER is presented. It is affected by factors related to the feelings and emotions that arise.

Several studies were presented in the Russian literature (e.g., Roshchina et al., 2018; Zakharova \& Tanasenko, 2019; Popova, 2016), which described the results related to the assessment of acceptance of 
online courses and the attitude of domestic faculty to them, as well as studying the motives of their activities and emotions associated with changes in the conditions and content of employment during the transition (full or partial) for e-learning. Summarizing, we can state that faculty have a loyal attitude to online courses generally, which is associated with the possibility of better organization of the learning process, mastering educational material, professional growth through the development of new competencies and acquiring a new experience, high resource efficiency (reducing the classroom load, free schedule, time flexibility, saving physical and voice resources) (Zakharova \& Tanasenko, 2019). The low willingness to work with online courses among university teachers is explained by high resource costs (significant time and labor costs associated with course development, support of the educational process on the platform, ensuring the relevance of course materials), which does not correlate with remuneration, difficulties in monitoring and identifying students who pass the test and control task, "depersonalization" of the educational process (Zakharova \& Tanasenko, 2019), risks of loss of accumulated "teaching rent", increased competition and even dismissal (Roshchina et al., 2018), as well as individual characteristics of faculty: "not everyone can create courses due to the individual characteristics of the teacher", and, for example, "lack of charisma"; "the format is not for third-age teaching staff" (Zakharova \& Tanasenko, 2019), and it is also associated with gaps in legislation related to intellectual property and property rights to online courses. According to the study participants, lecturers, who develop and integrate online courses into the educational process, are insured against dismissal due to online courses implementation. (Zakharova \& Tanasenko, 2019).

Based on the above results and theoretical conception, our study complements them by analyzing Russian faculty's subjective acceptance and motivations for developing online courses, taking into account the influencing of professionally significant factors, and identifying risks and threats associated with online courses. Looking ahead, we should note that the comparison of our survey results (described below) with the results of the studies mentioned above indicates their qualitative and quantitative consistency.

\section{DATA AND METHODS}

\section{Survey Design}

Methods of qualitative and quantitative analysis were used in the study. We designed the sociological survey of lectures among various Russian universities. We conducted the survey in JanuaryFebruary 2020 on the use of electronic forms of a questionnaire. During this period, the issue of the coronavirus pandemic was not yet super relevant in Russia. At that time, the respondents could not have known that university education would become remote soon. An electronic questionnaire was developed using the technology of docs.google.com. The questionnaire contained 16 questions: 9 of them aimed to shape a socio-professional respondent's portrait, six key questions aimed to identify the respondent's experience of using digital technologies, and their attitude to the digitalization of higher professional education in general elements in particular. The last question of the questionnaire was open and allowed to express the respondent's opinion and identify factors that were not stated in the questionnaire. In total, the questionnaire allowed us to evaluate 103 variables.

The study did not examine data on the number of online courses developed by respondents. We focused on understanding and identifying lecturers' attitudes that can influence the motivation to design online courses and identifying the challenges and threats accompanying faculty employment when integrating online courses into educational programs.

The research tasks were (1) to analyze lecturers opinions regarding the availability and application of their own and others' (from various repositories) online courses; (2) to reveal factors and motives that influence the creation and usage of the online course; (3) to analyze factors that determine the threats to the employment of faculty due to the widespread introduction of online courses. 


\section{Data Collection}

The invitation to participate in the survey was distributed using the "snowball" method. First of all, the invitation to participate in the survey was distributed through personal networks and contacts of the authors, as well as in the form of direct requests to the email addresses of Russian university teachers received from open access (including those indicated as contacts of the authors of various publications), and proposals in social networks. Those who responded to the survey were also asked to distribute the link to fill out the questionnaire to other faculty they knew. The data collection process continued until actions to distribute the link to the questionnaire to attract new participants stopped increasing the number of respondents (Lovakov, 2015).

\section{Data Description}

We interviewed 134 lecturers from Russian universities $(\mathrm{N}=134)$. Among the survey participants, the main share is women, the significant number of them are in the age range from 41 to 50 years, have $10+$ years of teaching experience in higher education (Table 1). The majority of respondents have the position of associate professor (53\%), 67\% of respondents are specialists in the humanities and social subject areas.

Potential participants were notified about the anonymity of the survey in a letter when the link was distributed. In total, for qualitative analysis, questionnaires were received from faculty of government universities (further in the text are GUs), federal universities (further in the text are FUs), national research universities (further in the text are NRUs), flagship universities (further in the text are FSUs), and other universities that do not have the status and category (further in the text are OUs).

\section{TABLE 1}

\section{THE MAIN CHARACTERISTICS OF THE RESPONDENTS}

\begin{tabular}{|c|c|c|c|}
\hline Variablesistepis & Mean, $\%(\mathrm{~N})$ & 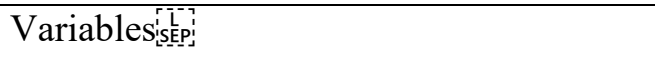 & Mean, $\%(\mathrm{~N})$ \\
\hline Gender: & & Occupy positions: & \\
\hline Male & $32,1(44)$ & \multirow{2}{*}{$\begin{array}{l}\text { Administrative and managerial staff and } \\
\text { combining the position of lecturer }\end{array}$} & \multirow{2}{*}{$7,6(10)$} \\
\hline Female & $67,9(90)$ & & \\
\hline Age, years: & $2,2(3)$ & $\begin{array}{l}\text { Head of the Department, head of the } \\
\text { laboratory, and combining the position of } \\
\text { lecturer }\end{array}$ & $13,6(18)$ \\
\hline $31-40$ & $23,1(30)$ & Professor & $12,9(17)$ \\
\hline $41-50$ & $36,6(49)$ & Associate professor & $53,0(71)$ \\
\hline $51-60$ & $20,9(29)$ & Senior lecturer, lecturer & $11,4(15)$ \\
\hline $60+$ & $17,2(23)$ & \multirow{2}{*}{$\begin{array}{l}\text { Research associate with the combined } \\
\text { position of lecturer }\end{array}$} & \multirow[b]{2}{*}{$1,5(2)$} \\
\hline $\begin{array}{l}\text { Work experi } \\
\text { years: }\end{array}$ & lecturer, & & \\
\hline $1-5$ & $3,0(4)$ & University category: & \\
\hline $6-10$ & $5,2(7)$ & $F U$ & $26,9(36)$ \\
\hline $11-20$ & $38,8(52)$ & $N R U$ & $9,0(12)$ \\
\hline $21-30$ & $34,3(46)$ & $F S U$ & $26,1(35)$ \\
\hline $31-40$ & $13,4(18)$ & $O U$ & $35,8(48)$ \\
\hline $40+$ & $5,2(7)$ & $G U$ & $2,2(3)$ \\
\hline
\end{tabular}

\section{Methods}

We applied various statistical methods to perform quantitative analysis. Notably, we computed descriptive statistics and the distributions of responses to the main questions. We used the Chi-squared test to test the statistical significance of differences in the distribution of respondents' opinions. 


\section{RESULTS AND DISCUSSIONS}

The vast majority of lecturers who participated in the survey were familiar with e-learning technologies and used various types in courses and disciplines (Table 2).

\section{TABLE 2}

THE DISTRIBUTION OF ANSWERS TO THE QUESTION "WHAT DIGITAL TECHNOLOGIES DO YOU USE TO TEACH STUDENTS?”, \% OF RESPONDENTS

\begin{tabular}{lcccc}
\hline \multirow{2}{*}{ Variables } & \multicolumn{3}{c}{ University category } & Average for \\
\cline { 2 - 5 } & $\begin{array}{c}\text { FUs \& NRUs \& } \\
\text { GUs }\end{array}$ & FSUs & OUs & the sample \\
\hline Multimedia presentations * & 87,5 & 82,9 & 98,0 & 90,2 \\
\hline $\begin{array}{l}\text { Communication (including consulting) } \\
\begin{array}{l}\text { with students and students through } \\
\text { digital communications (email, chat, } \\
\text { etc.) }\end{array}\end{array}$ & 75,0 & 62,9 & 83,7 & 75,0 \\
\hline $\begin{array}{l}\text { Own course in MOODLE or a course } \\
\text { presented on an online platform** }\end{array}$ & 35,4 & 68,6 & 36,7 & 44,7 \\
\hline Remote classes on the Internet * & 25,0 & 28,6 & 44,9 & 33,3 \\
\hline Communication via LMS & 6,3 & 8,6 & 10,2 & 8,3 \\
\hline
\end{tabular}

Note: $*, * *$ - the statistical significance of differences in the distribution of responses according to the Chi-squared test with a confidence probability of 0.1 and 0.5 , respectively. The sum of the shares in the column exceeds 100 because the respondent can select several options in the list.

Thus, $90 \%$ of the lecturers who participated in the survey use multimedia presentations in their teaching activities. At the same time, $98 \%$ of OUs' lecturers use multimedia presentations in teaching, and almost $84 \%$ of the surveyed lecturers communicate and advise students through digital communications (on average, $75 \%$ of the sample of lecturers engaged in digital communication with students).

Less than half of the respondents (45\%) have their own online courses on online platforms or in MOODLE. Distance learning is practiced much less frequently (25\%). Working in LMS is not very familiar to lecturers and is practiced much less often, regardless of university category.

Answering distance learning at the university, lecturers expressed their opinions about the feasibility of finding a compromise between online and offline learning:

"In my opinion, the electronic educational environment must be present at universities to meet the requirements of modernity. The main thing is not to lose the balance between online and offline forms of education. It is necessary to find their optimal combination that affects the quality of educational services of the university" (Q\#61).

Some respondents assessed the transition to the digitalization of universities as a variant of reengineering process activities at the university:

"The digital university, to a greater extent, is business processes, not training" ( $Q \# 14)$.

"I have a lot of experience with distance learning (more than ten years), but I see online courses as profanation through total unification (which does not allow training professionals), formalism and primitivism..." (Q\#15). 
Opinions were expressed against the complete transition to e-learning:

"I believe that digital courses should only serve as a supplement to traditional education, and I emphasize that this is the position of many lecturers" (\#Q80).

These answers were justified by the possibility of losing "live communication":

"E-courses are certainly an interesting innovation, but communication-based on the emotional contact of the teacher and the student should be put at the forefront" (Q\#45).

"A student's direct contact with the lecturer cannot be replaced by any electronic communications or digital gadgets" (Q\#66).

Negative assessments of the prospects for the introduction of digital technologies are related to their possible negative impact on the future of universities:

"I believe that the digitalization of universities will eventually destroy half of the good Russian universities, the tradition of original Russian education" (Q\#13);

"For us, online education is an indirect way of destroying education" (Q\#37).

"Forms of contact in the context of electronic communication do not contribute to the individual's socialization. We create the problem of loneliness (the experience of Japan should be taken into account). I believe that the form of communication [when introducing online courses] radically changes the content, and education may lose its educational function" (Q\#50).

"Exclusively e-learning in biological and chemical fields is not possible" (Q\#91).

The survey participants were asked to express their opinion on which courses would be more effective for the Russian high education system: MOOC or TOC (Targeted Online Course). The lecturers' views regarding the mass orientation of courses or specialized courses for respondents of all university categories are statistically indistinguishable (Table 3): 23\% of respondents believe that the rate should be placed on special online courses, $40 \%$ - think that along with targeted online courses, mass courses should not be abandoned, and $15 \%$ - could not formulate their own position.

"The difference between TOC and MOOC is far-fetched. It may be essential for a marketer who promotes educational programs. The content of the course is important, not the abbreviation" ( $Q \# 98)$. 
TABLE 3

\section{DISTRIBUTION OF ANSWERS TO THE QUESTION "DO YOU THINK THAT RUSSIAN DIGITAL UNIVERSITIES SHOULD FOCUS MORE ON TOCS RATHER THAN MOOCS", \% OF RESPONDENTS}

\begin{tabular}{lcccc}
\hline \multirow{2}{*}{ Variables } & \multicolumn{2}{c}{ University category } & \multicolumn{2}{c}{$\begin{array}{c}\text { Average for the } \\
\text { sample }\end{array}$} \\
\cline { 2 - 5 } & FUs \& NRUs \& GUs & FSUs & OUs \\
\hline Yes. I fully agree with this position. & 23.9 & 23.5 & 22.7 & 23.4 \\
\hline $\begin{array}{l}\text { Yes. I am inclined to this point of } \\
\text { view, but MOOCs are needed no less. }\end{array}$ & 43.5 & 32.4 & 43.2 & 40.3 \\
\hline $\begin{array}{l}\text { No needs to bet on TOCs. It is not } \\
\text { beneficial to the university or the } \\
\text { lecturers. }\end{array}$ & 4.3 & 8.8 & 9.1 & 7.3 \\
\hline $\begin{array}{l}\text { No. I believe MOOCs are more } \\
\text { profitable for the university both from } \\
\text { the economic side and from the point } \\
\text { of view of demand. }\end{array}$ & 10.9 & 20.6 & 11.4 & 13.7 \\
\hline \begin{tabular}{l} 
It is difficult to answer \\
\hline
\end{tabular} & 17.4 & & & \\
\hline
\end{tabular}

The responses of some lecturers articulated the rejection of any online courses.

"MOOCs are not about learning, but about promoting knowledge. TOCs are applicable for a limited category of students only" (Q\#14).

When conducting a survey, the task was to form an idea of how many Russian lecturers took online courses and how many of them are developers of their own courses presented on various platforms (Table 4). It was found that $54 \%$ of respondents have their own online courses. The distribution of responses reflecting the presence/absence of online courses among university lecturers of various categories was almost uniform. Statistically insignificant, but still higher frequency of their own online courses is observed among the lecturers from FSUs who participated in the survey. At the same time, $60 \%$ of FSUs' respondents have more than $70 \%$ of the classroom load in total employment at the university, and $31 \%$ - teach more than seven training courses in the academic year.

\section{TABLE 4}

AVAILABILITY OF ONLINE COURSES AND GENERAL INDICATORS OF RESPONDENTS' UNIVERSITY EMPLOYMENT, \% OF RESPONDENTS

\begin{tabular}{|c|c|c|c|c|c|c|c|c|}
\hline \multirow[t]{2}{*}{$\begin{array}{l}\text { University } \\
\text { category }\end{array}$} & \multirow{2}{*}{$\begin{array}{l}\text { Lecturers who } \\
\text { have their } \\
\text { own online } \\
\text { courses }\end{array}$} & \multicolumn{4}{|c|}{$\begin{array}{l}\text { The proportion of "auditory load" in } \\
\text { total employment }\end{array}$} & \multicolumn{3}{|c|}{$\begin{array}{c}\text { Number of courses } \\
\text { taught in an academic } \\
\text { year }\end{array}$} \\
\hline & & $<30 \%$ & $30-50 \%$ & $50-70 \%$ & $>70 \%$ & $1-3$ & 4-7 & $>7$ \\
\hline $\begin{array}{l}\text { FUs \& NRUs \& } \\
\text { GUs }\end{array}$ & 52.1 & 14.6 & 18.8 & 20.8 & 45.8 & 43.8 & 47.9 & 8.3 \\
\hline FSUs & 57.1 & 5.7 & 20.0 & 14.3 & 60.0 & 17.1 & 51.4 & 31.4 \\
\hline OUs & 53.1 & 24.5 & 16.3 & 24.5 & 34.7 & 32.7 & 46.9 & 20.4 \\
\hline $\begin{array}{l}\text { Average for the } \\
\text { sample }\end{array}$ & 53.8 & 15.9 & 18.2 & 20.5 & 45.5 & 32.6 & 48.5 & 18.9 \\
\hline
\end{tabular}


The interviewed lecturers, who are the authors of online courses, noted various factors that influence the creation (Figure 2).

FIGURE 2

\section{DISTRIBUTION OF RESPONSES TO THE QUESTION “GIVE YOUR OPINION ON THE AVAILABILITY AND USE OF YOUR OWN ONLINE COURSES" (AMONG LECTURERS WHO HAVE THEIR OWN ONLINE COURSES ON VARIOUS PLATFORMS), \% OF RESPONDENTS}

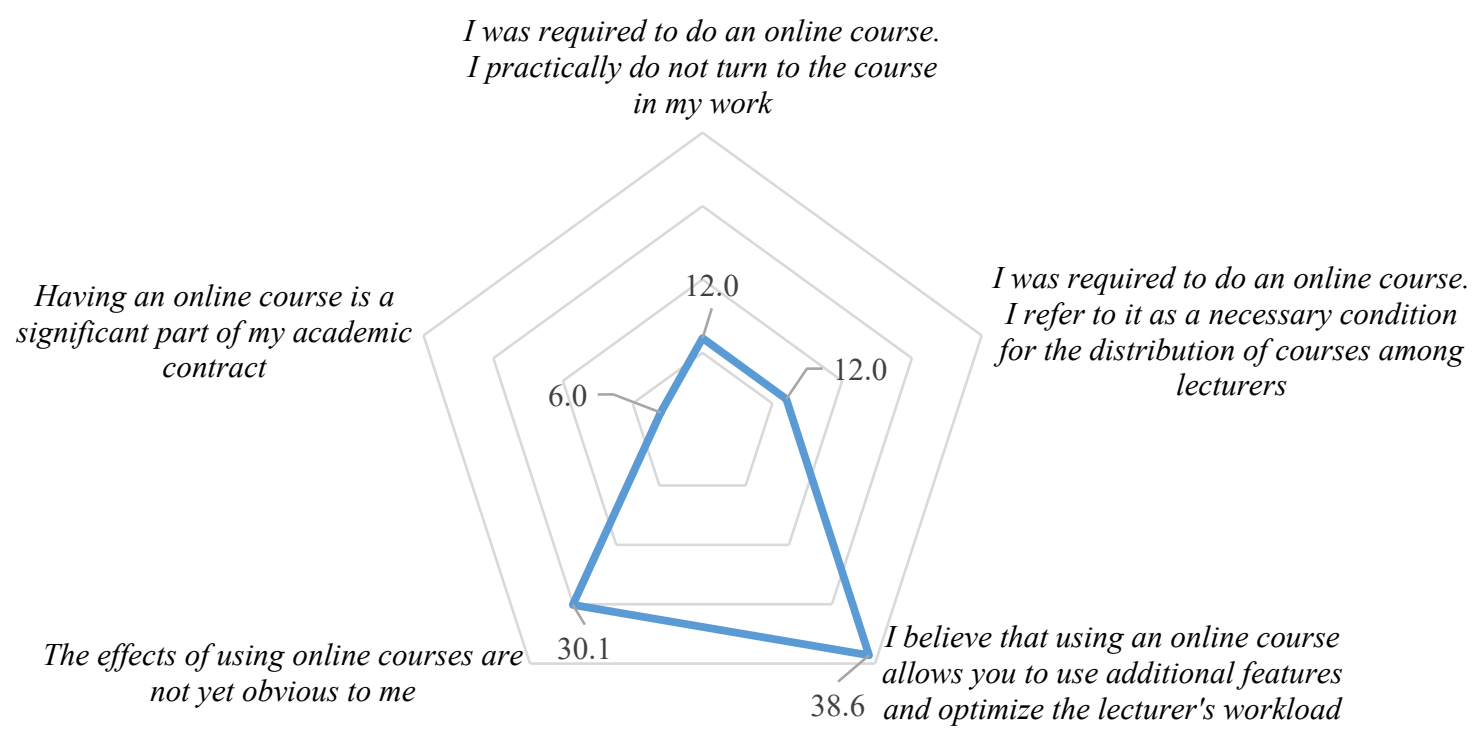

Thus, $30 \%$ of the surveyed lecturers who have their own online courses noted that creating an online course are either (a) a response to the responsibilities assigned to develop it ("I was required to do it") is $24 \%$, or (b) a necessary condition for fulfilling an effective contract is $6 \%$. Almost $39 \%$ of respondents positively assess the experience of developing and applying for the developed online course, as they believe that it "allows you to use additional features and optimize the load of the lecturer", and thus indicate its resource efficiency, 30\% noted the non-obvious effects of the application, $12 \%$ of respondents who developed the online course articulated the formality of the online course since they practically do not use it in their activities.

Respondents noted that they were motivated to create their own online courses: motivation to pay extra for the course, readiness to intensify work in accordance with indicators for financial incentives (35\%), motivation to take a worthy place among other teachers and creators of online courses (16\%), motivation to add to the "portfolio of their own achievements" in order to protect themselves from the possibility of being an unclaimed specialist (35\%), motivation to avoid stress that can be caused by a low assessment of competencies and teaching work by management $(8 \%)$, the motive to make the results of their research in the relevant subject field public (25\%), the motive to fulfill professional duty, to obtain moral satisfaction from the content and quality of their professional activities $(25 \%)$, the motive to ensure moral satisfaction from teaching at a university that has a good reputation and occupies a worthy place in the university rating $(8 \%)$, also respondents indicated the need to fulfill the mandatory requirement of an effective contract, the need to comply with the conditions when switching to another university, the desire to try yourself as a developer.

In the "free" part of the questionnaire, respondents expressed the following arguments in favor of creating and using online courses: 
"E-learning is a mandatory attribute of modern higher education. A modern teacher must not only know and be able to use the attributes of electronic resources but also have their own online course" (Q\#6).

"... This can expand the boundaries of education for the applicant; on the other hand, it requires more discipline from the student and teacher, and leads to the abolition of the classroom load in educational institutions" (Q\#29).

"E-learning is a great additional option that significantly expands opportunities for both students and lecturers" (Q\#57).

Slightly less than half of the respondents do not have their own online courses. The reasons for not developing them so far are diverse (Figure 3).

\section{DISTRIBUTION OF RESPONSES TO THE QUESTION “GIVE YOUR OPINION ON THE AVAILABILITY AND USE OF YOUR OWN ONLINE COURSES” (AMONG LECTURERS WHO DO NOT HAVE THEIR OWN ONLINE COURSE), $\%$ OF RESPONDENTS}

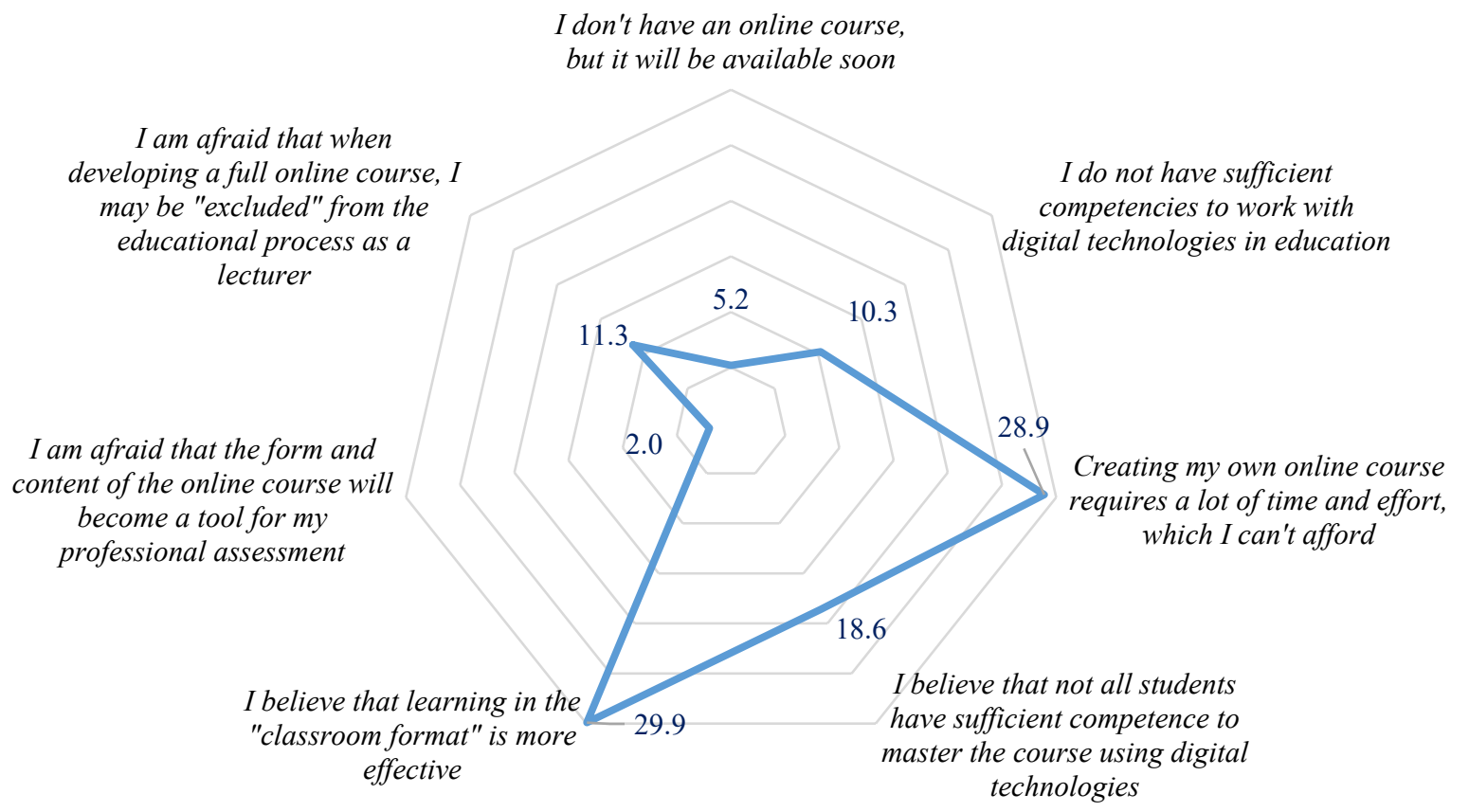

Note: When answering a question, you can choose several options, so the sum of the shares in the column exceeds 100.

Thus, $5 \%$ of respondents indicated that they would have online courses in the near future. Almost $30 \%$ of those who do not have online courses attribute their absence to the lack of relevant competencies among participants in the educational process: $10 \%$ of lecturers indicate that their own competencies are insufficient to work with digital educational technologies, and $19 \%$ of lecturers believe that not all 
students have the competencies to work and master online courses. For $13 \%$ of the surveyed lecturers, the lack of their own online course is associated with a fear of negative professional evaluation ( $2 \%)$ or fear of being excluded from the educational process (11\%). Almost $30 \%$ of respondents still believe that learning in the "classroom" format is more effective than online learning, which stops them from developing their own online courses. $29 \%$ of the lecturers surveyed rate the development of their own online courses as a high resource-intensive process.

To assess the respondents' fears due to threats to employment in higher education related to the development and implementation of online courses, we used the question: "Is there a threat to your employment at the university with the widespread introduction of digital technologies in the educational process?". In general, the opinions of lecturers regarding the presence or absence of possible threats to their employment in connection with the digitalization of higher education and the introduction of online courses were divided as follows: $46 \%$ articulated their sense of threats to employment and changes in the structure and content of work at the university (responses with a confirmed threat), 54\% - do not see threats to their own employment (responses with an unconfirmed threat).

The opinions and judgments about changing conditions and threats to employment in universities are shown in Figure 4.

\section{FIGURE 4 \\ DISTRIBUTION OF ANSWERS TO THE QUESTION "IS THERE A THREAT TO YOUR EMPLOYMENT AT THE UNIVERSITY WITH THE WIDESPREAD INTRODUCTION OF DIGITAL TECHNOLOGIES IN THE EDUCATIONAL PROCESS?" (RESPONSES WITH A CONFIRMED THREAT), \% OF RESPONDENTS}

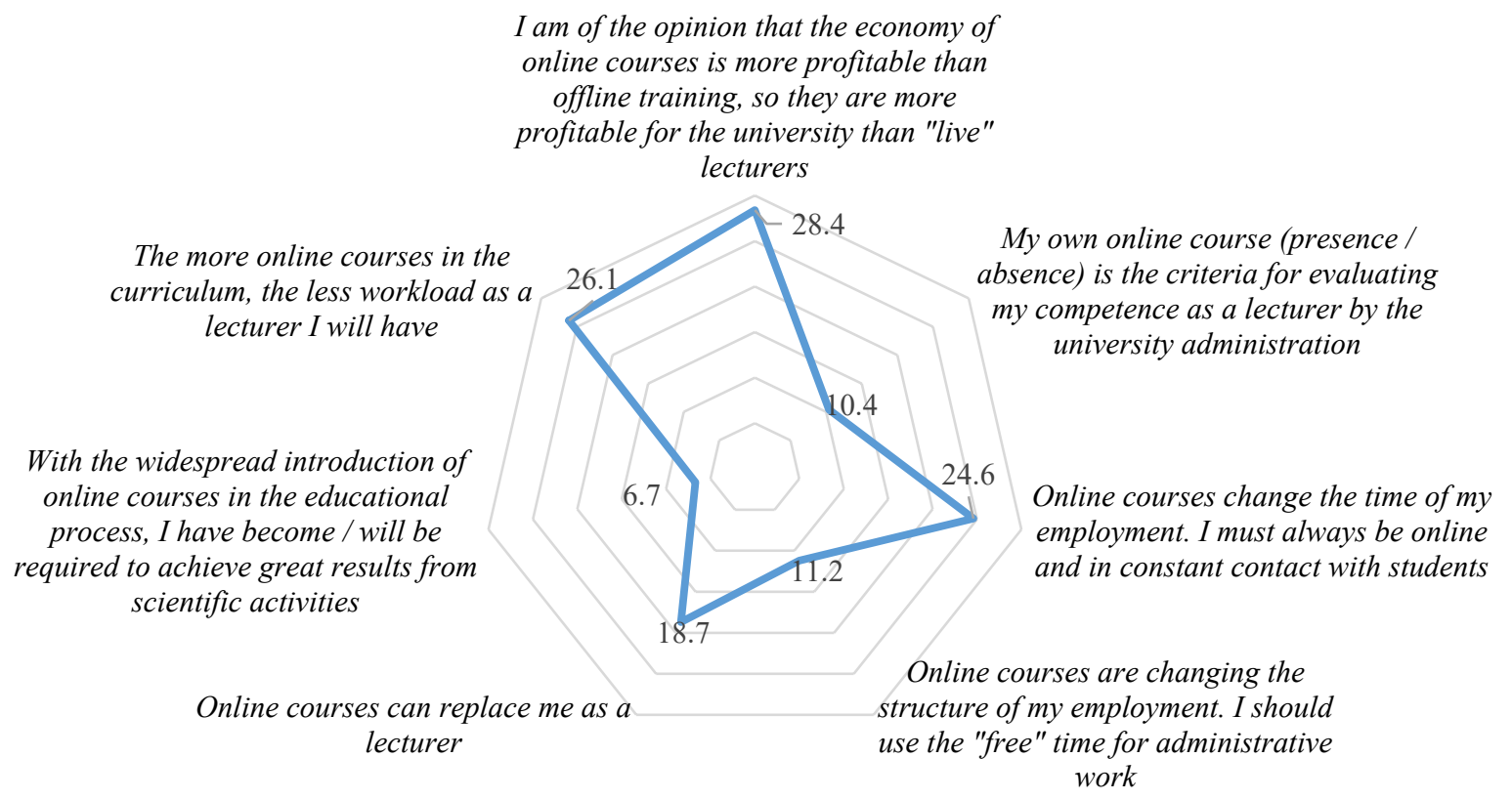

Note: When answering a question, you can choose several options, so the sum of the shares in the column exceeds 100 .

Among the lecturers who identified a threat to employment, $36 \%$ noted that digitalization and introduction of online courses affects the structure and time of their career, may affect the overall academic load, which is the main activity of the lecturer, and $19 \%$ believe that online courses can 
completely replace "live" lecturers, which, among other things, is determined by the economy of online education. $11 \%$ of respondents expressed concern that they will have to take administrative work as a result of the implementation of online courses, and another $7 \%$ believe that they will be required to achieve higher results in scientific activities.

In this regard, the respondent's opinion deserves attention:

"The burden on teachers reduced every year, many departments become high 0.75 bets, and the amount of payment depends on the load, an effective contract is one - time payment ... - not so motivating incentive...., there is also the risk of lower demand for teachers, if discipline will be provided e-learning courses" (Q\#60).

The distribution of responses from interviewed lecturers who do not express a sense of threat to employment at the university is shown in Figure 5.

\section{FIGURE 5 \\ DISTRIBUTION OF ANSWERS TO THE QUESTION “ARE THERE ANY THREATS TO YOUR EMPLOYMENT AT THE UNIVERSITY WITH THE WIDESPREAD INTRODUCTION OF DIGITAL TECHNOLOGIES IN THE EDUCATIONAL PROCESS?" (RESPONSES WITH AN UNCONFIRMED THREAT), \% OF RESPONDENTS}

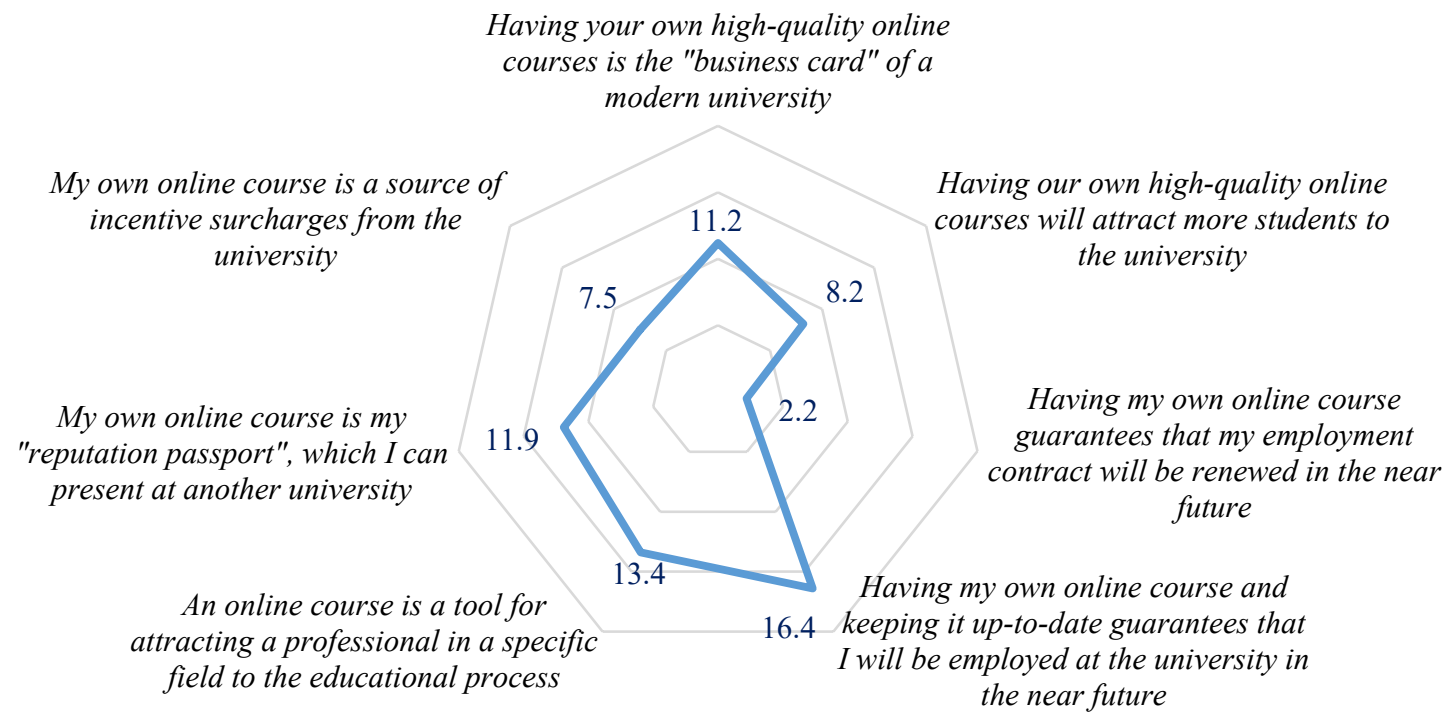

Note: When answering a question, you can choose several options, so the sum of the shares in the column exceeds 100.

More than half of the respondents did not identify a threat to their employment at the university due to the transition to e-learning because, on the one hand, they make a connection between high-quality online courses and increasing the "awareness" and improving the brand of the university $(11 \%)$, which will attract more students to the university (8\%) and qualified lecturers (13\%), on the other hand, 19\% are sure that having their own high-quality online courses is a kind of guarantee of renegotiation of employment contracts with them. Some of the lecturers who participated in the survey see their own 
benefits in developing online courses related to improving their personal professional reputation (12\%) and financial income $(7.5 \%)$.

The analysis of lecturers' predisposition to a negative attitude of digitalization of education, which creates a threat to their employment, is based on a logistic regression model that includes the main personal characteristics, position, teaching load, field of science, and category of an educational institution (Table 5).

TABLE 5

THE RESULTS OF EVALUATING THE PARAMETERS OF THE LOGISTIC REGRESSION MODEL $(Y=\{1,0\})$, THE RESULT OF THE ANSWER TO THE QUESTION “ARE THERE ANY THREATS TO YOUR EMPLOYMENT AT THE UNIVERSITY WITH THE WIDESPREAD INTRODUCTION OF DIGITAL TECHNOLOGIES IN THE EDUCATIONAL PROCESS?"

\begin{tabular}{|c|c|c|c|c|}
\hline The respondents' characteristics & Parameter & p-value & \multicolumn{2}{|c|}{$\begin{array}{l}95 \% \text { confidence } \\
\text { interval }\end{array}$} \\
\hline Age & -0.003 & 0.910 & -0.049 & 0.044 \\
\hline Gender $($ male $=1 ;$ female $=0)$ & -0.684 & 0.151 & -1.617 & 0.249 \\
\hline $\begin{array}{l}\text { Occupy positions: } \\
\text { Head of the Department, head of the laboratory } \\
\text { and combining the position of lecturer }\end{array}$ & -0.649 & 0.486 & -2.478 & 1.179 \\
\hline Professor & -1.240 & 0.202 & -3.146 & 0.665 \\
\hline Associate professor & 0.279 & 0.740 & -1.370 & 1.929 \\
\hline Senior lecturer, lecturer & 0.978 & 0.345 & -1.052 & $3.009)$ \\
\hline $\begin{array}{l}\text { The share of the audience load in the total } \\
\text { employment of the lecturer }(\%)^{* * *}\end{array}$ & 0.029 & 0.004 & 0.009 & 0.049 \\
\hline $\begin{array}{l}\text { University category: } \\
\text { FU \& NRU \& GU }(\mathrm{Yes}=1 ; \mathrm{No}=0) * *\end{array}$ & -1.550 & 0.047 & -3.082 & -0.018 \\
\hline FSU $(\mathrm{Yes}=1 ; \mathrm{No}=0)$ & 0.569 & 0.351 & -0.626 & 1.763 \\
\hline Constant & 0.228 & 0.858 & -2.283 & 2.740 \\
\hline
\end{tabular}

Note: $\mathrm{R}^{2}$ pseudo $=0.175 ; \operatorname{Ln}(\mathrm{L}(0))=-84.7 ; \operatorname{Ln}(\mathrm{L}(\mathrm{x}))=-69.8 ; \operatorname{Prob}\left(X^{2}\right)=0.0017-$ probability that all coefficients of the model are equal to zero according to the $X^{2}$ criterion.

$*, * *, * * *$ - the statistical significance of the model parameter according to the z-criterion with a confidence probability of $0.1,0.05,0.01$, respectively.

It was found that age and gender factors, as well as the respondent's position, do not affect the acceptance of online courses by lecturers. At the same time, it was found that lecturers who have a high share of the audience load in total employment more acutely assess the threat of their own employment (the coefficient with the variable 0.029 is positive and has a high significance, the sign of the coefficient is constant within the confidence interval). This circumstance allows us to conclude that the probability of finding lecturers who assess the availability of online courses as a threat to their own employment increases with increasing classroom load.

In general, this result is natural. Indeed, for lecturers whose main field of activity is "live" learning, an online course can be considered a potential reduction in the hours allocated to a particular lecturer for a discipline. As a result, there is a threat to their employment at this university. FUs, NRUs, and GUs' lecturers are less likely to view online courses as a threat to their careers.

\section{CONCLUSION}

Since the education digitalization is based on the diffusion of digital educational resources to reach a critical mass of users, the authors put forward the thesis that understanding the behavior of lecturers 
in accepting online courses, the level and factors of lecturers' attitude is essential, if a not crucial, issue in this process. Along with the discussion of whether online courses are "good" or "evil" for the higher education system, issues related to assessing the effects, motives, and threats to the direct participants in the digitalization of education of university lecturers should be studied. Our research collected responses from the Russian universities' lecturers about their attitudes toward the digitalization of education, their level of knowledge about open educational resources, in particular about online courses, and their readiness to work with the use of e-learning technologies. Survey participants identified their concerns and concerns about changes in employment conditions at universities and their motivations for developing and integrating online courses.

\section{REFERENCES}

Carnoy, M., \& Kuzminov, Y. (2015). How It Affects the University Structure and Economics. Educational Studies Moscow, 3, 8-43. https://doi.org/10.17323/1814-9545-2015-3-8-43

Chae, B., \& Jenkins, M.A. (2015). Qualitative Investigation of Faculty Open Educational Resource Usage in the Washington Community and Technical College System: Models for Support and Implementation. Retrieved February 5, 2020, from https://drive.google.com/ file/d/0B4eZdZMtpULyZC1NRHMzOEhRRzg/view

Chekhonina, O.B., \& Kuznetsova, S.A. (2019). Mass open online courses as a means of advanced training for a university teacher. In Experience and prospects of online education in Russia: A collection of articles of the All-Russian scientific conference with international participation "Experience and prospects of online education in Russia". Sevastopol, November 15-16, 2018. Sevastopol: Branch of Moscow State University in Sevastopol.

Cox, G., \& Trotter, H. (2017). An OER framework, heuristic, and lens: Tools for understanding lecturers' adoption of OER. Open Praxis, 9(2), 151-171. https://doi.org/10.5944/openpraxis.9.2.571

Daniel, J.D. (2012). Making sense of MOOCs: Musings in a maze of myth, paradox, and possibility. Journal of Interactive Media in Education, 3. http://doi.org/10.5334/2012-18

Friedman, T.L. (2013, January 26). Revolution hits the universities. The New York Times. Retrieved February 5, 2020, from http:/www.nytimes.com/2013/01/27/opinion/sunday/friedmanrevolution-hits-the-universities.html

Hennessy, S., Haßler, B., \& Hofmann, R. (2015). Challenges and opportunities for teacher professional development in interactive use of technology in African schools. Technology, Pedagogy and Education, 24(5), 1-28. https://doi.org/10.1080/1475939X. 2015.1092466

Ikahihifo, T.K., Spring, K.J., Rosecrans, J., \& Watson, J. (2017). Assessing the savings from open educational resources on student academic goals. International Review of Research in Open and Distributed Learning, 18(7), 126-140.

Kuznetsov, N. (2019). Online education: key trends and barriers. E-Management, 1, 19-25. https://doi.org/ 10.26425/2658-3445-2019-1-19-25

Literat, I. (2015). Implications of massive open online courses for higher education: Mitigating or reifying educational inequities? Higher Education Research \& Development, 34(6), 1164 1177. https://doi.org/10.1080/07294360.2015.1024624

Lovakov, A. (2015). The commitment of Russian University Teachers to University and Profession. Educational Studies Moscow, 2, 109-128. https://doi.org/ 10.17323/1814-9545-2015-2-109-128

Marshall, S. (2014). Exploring the ethical implications of MOOCs. Distance Education, 35, 250-262. https://doi.org/10.1080/01587919.2014.917706

Mozhaeva, G.V. (2019). Digitalization in modern education: From online courses to data analysis. Report presentation. Retrieved March 1, 2020, from http://nvsu.ru/ru/Intellekt/2149/Lekciya_ Mozhaeva_Cifrovizaciya_v_sovremennom_obrazovanii.pdf

Pappano, L. (2012, November 14). The Year of the MOOC. The New York Times. Retrieved February 25, 2020, from https://aurapappano.com/articles/the-year-of-the-mooc/ 
Popova, A.O. (2016). Key motivators for setting up an online course: Expectations and initial results. Modern Information Technologies and IT-Education, 3(2), 75-82.

Rolfe, V. (2017). Striving Toward Openness: But What Do We Really Mean? The International Review of Research in Open and Distributed Learning, 18(7). https://doi.org/10.19173/irrodl.v18i7.3207

Roshchina, Y., Roshchin, S., \& Rudakov, V. (2018). The Demand for Massive Open Online Courses (MOOC): Evidence from Russian Education. Educational Studies Moscow, 1, 174-199. https://doi.org/ 10.17323/1814-9545-2018-1-174-199

Tretyakov, V.S., \& Larionova, V.A. (2016). Open education as a university development strategic direction. University Management: Practice and Analysis, 2(102), 51-60. http://doi.org/10.15826/umj.2016.102.004

Tulchinskii, G.L. (2017). Digital Transformation of Education: Challenges for Higher School. Philosophical Sciences, 6, 121-136.

Weller, M., de los Arcos, B., Farrow, R., Pitt, B., \& McAndrew, P. (2015). The Impact of OER on Teaching and Learning Practice. Open Praxis, 7(4), 351-361. https://doi.org/10.5944/openpraxis.7.4.227

Zakharova, U., \& Tanasenko, K. (2019). MOOCs in Higher Education: Advantages and Pitfalls for Instructors. Educational Studies Moscow, 3, 176-202. https://doi.org/ 10.17323/1814-9545-20193-176-202 